\title{
O MANIFESTO COMUNISTA: HISTÓRICO E PRESSUPOSTOS
}

\author{
André Luis Castro de Freitas ${ }^{1}$ \\ Luciane Albernaz de Araujo Freitas ${ }^{2}$
}

\begin{abstract}
RESUMO
A partir de um estudo descritivo crítico, fundamentado em uma pesquisa qualitativa, bibliográfica, adensada pelo pensamento de Karl Marx e Friedrich Engels, tem-se como intenção refletir sobre os pressupostos discutidos na obra - Manifesto comunista, sua origem, organização e impacto. A ideia fundamental que percorre o Manifesto é que, dado um contexto histórico, a produção econômica e a estrutura social que dela decorre constituem a base da história política e intelectual de uma época. Tal proposição constitui o estudo de uma luta de classes entre exploradores e explorados.
\end{abstract}

Palavras-chave: Luta de classes; Proletários; Socialismo; Comunismo.

\section{THE COMMUNIST MANIFESTO: HISTORY AND ASSUMPTIONS}

\begin{abstract}
This work aims to reflect on the presuppositions discussed in the work the Communist Manifesto, their origin, organization and impact, based on a qualitative, bibliographical research based on the thought of Karl Marx and Friedrich Engels, based on a critical descriptive study. The fundamental idea of the Manifesto is that, given a historical context, the economic production and the social structure that stems from it constitute the basis of the political and intellectual history of a historical time. Such a proposition constitutes the study of a class struggle between exploiters and exploited.
\end{abstract}

Key-words: Class conflict; Proletarians; Socialism; Communism.

\footnotetext{
${ }^{1}$ Docente da Universidade Federal do Rio Grande (FURG) e do Programa de Pós-Graduação em Educação Ambiental (PPGEA/FURG).

${ }^{2}$ Docente do Instituto Federal Sul-rio-grandense (IF SUL) e do Programa de Pós-Graduação em Educação Profissional e Tecnológica. Doutora em Educação Ambiental.
} 


\section{CONSIDERAÇÕES INICIAIS}

A obra o Manifesto comunista consistiu em propor ao moviemnto operário, na Inglaterra do século XIX, durante a Revolução Industrial, uma política com fundamentação científica, em prol da luta por objetivos concretos, para a classe operária. O objetivo final deveria ser a conquista do poder do Estado e a criação de um programa de transformação comunista da sociedade.

A proposição fundamental do Manifesto foi elaborada por Karl Marx e segundo Engels (2016) essa proposta é de que, em cada contexto histórico, a produção econômica, o sistema de trocas e a estrutura social que dela decorre constituem a base, a explicação e a compreensão da história política e intelectual de uma dada época. Nessa conjuntura, estava presente a luta de classes, os conflitos entre aqueles que exploram e os explorados, tal que esses últimos, os proletários, representam a classe oprimida e os primeiros a burguesia, a qual mantinha a exploração e a opressão.

A intencionalidade do texto é problematizar, a partir das ideias de Marx e Engels, a indissociável visão entre os proletários e os burgueses frente à luta de classes, dado um momento histórico. O texto está descrito da seguinte forma: O momento histórico - discute-se a gênese do Manifesto comunista e o seu surgimento em meio ao contexto da Revolução Industrial; O Manifesto comunista: dialética e revolução - reflete-se sobre o impacto revolucionário do documento; Burgueses e proletários - faz-se uma retomada do surgimento e a relação constituída entre as das duas classes; Proletários e comunistas diferenciam-se as duas categorias, principalmente, no que tange aos interesses nacionais e Socialismo e comunismo - realizam-se reflexões sobre o perfil dos pensadores frente ao movimento revolucionário. Após seguem as considerações finais.

\section{O MOMENTO HISTÓRICO}

A obra o Manifesto comunista foi publicada no ano de 1848, entre o final de fevereiro e o iníco de março, em Londres. A obra teria sido encomendada pela Liga dos Comunistas em novembro de 1847, dado o período de efervecência revolucionária o qual vivia a Europa. Sua publicação 
foi, ainda, apressada em função da Revolução de Fevereiro $^{3}$ acontecida na França.

No final de janeiro, a direção da Liga dos Comunistas enviou a Karl Marx uma carta intimando o autor a apresentar a obra, argumentando sobre a possível devolução dos documentos emprestados a esse. Para Coggiola (2016) o Manifesto comunista coincidiu com a revolução a qual aconteceu na Suiça, espalhando-se, rapidamente, pela Itália e França, posteriormente, para a Renânia, Prússia, Austria e Hungria.

A Liga dos Comunistas, a qual tem sua fundação datada em 1836, inicialmente como Liga dos Justos, era composta por trabalhadores artesãos alemães, em geral, de Londres, Bruxelas, Paris e algumas partes da Alemanha. Não se tratavam esses sujeitos de proletários trabalhando em grandes fábricas, mas aqueles sujeitos que foram atraídos pelas ideias e reflexões sobre a sociedade capitalista moderna propostas por Marx e Engels.

A Liga dos Justos, criada em 1834, como federação, de caráter secreto, em algumas seções como na França, Alemanha e Bélgica atuavam à luz do dia. A proposta de Marx exigia que se pusesse fim à propaganda secreta e que se criasse um movimento das massas.

Por sua vez, a Liga dos Justos teve sua origem na Liga dos Exilados, formada essa última por intelectuais e artesãos emigrados de diversos países. Desses, alguns artesãos e operários separaram-se dos intelectuais e formaram a Liga dos Justos. Nessas condições, a liga formada em sua maior parte por operários logo se tornou socialista, tendência essa que se desenvolveu com o levante frustrado ensaiado pelos blanquistas ${ }^{4}$ em 1839. A liga se fez

\footnotetext{
${ }^{3}$ Para Engels (2012, p.13), quando irrompeu a Revolução de Fevereiro os autores, Marx e Engels, encontravam-se na compreensão do que se refere às concepções das condições e do curso dos movimentos revolucionários, sob a influência da experiência histórica, principalmente, da ocorrida na França. A França dominara a história europeia desde 1789, tal que dela havia partido, também, o sinal para a revolução geral.

${ }^{4}$ Os blanquistas embasados nas ideias de um comunismo revolucionário, em que o Estado remediasse o problema social, proposto por Loius Auguste Blanqui, representavam o partido da maioria e os proudhonistas fundamentados nas ideias anarquistas de Pierre-Joseph Proudhon, em um sistema mutualista de liberdade de crédito, o partido da minoria, que cindiam Paris nesse período vivido na França após a Comuna de Paris.
} 
comunista, justamente, embasada em um socialismo revolucionário, comunismo, a partir das ideias do blanquismo.

Marx não aderiu, inicialmente, a Liga dos Justos, apesar da estima que possuía por seus pertencentes, tal que se filiou a liga, somente, no início de 1847, momento em que foram definidos novos estatutos em que se exigiam o fim da sociedade burguesa, fundada no antagonismo de classe, e desejava-se o estabelecimento de uma nova sociedade sem classes e sem a propriedade privada.

Para Coggiola (2016), a liga foi reorganizada para tornar-se democrática, depois que Marx e Engels exigiram que tudo aquilo que remetesse a "superstição autoritária" fosse suprimido. Dessa forma, a liga concentrou-se na propaganda pública, colocando fim aos métodos ditatoriais de direção.

Em 1847, foi aprovada a publicação da Revista Comunista em que foi utilizado o novo slogan da liga. A Liga dos Justos, anteriormente, adotava o slogan: "Todos os homens são irmãos" e quando, finalmente, adotou as concepções de Marx e, ainda, tornou-se comunista passou ao slogan existente no Manifesto comunista: "Proletários de todos os países, uni-vos".

Nessas condições, desde a mescla de um socialismo, ou mesmo um comunismo franco-inglês, e a filosofia alemã que se constituía como a doutrina secreta da liga, foi possível a partir de Karl Marx uma observação científica da estrutura econômica da sociedade burguesa, como fundamento para que se construisse um sistema com a participação consciente dos sujeitos no processo histórico da revolução social.

A passagem de uma sociedade secreta para uma sociedade de operários comunistas foi um complexo processo histórico o qual sofreu, de mesma maneira, a influência do movimento Cartista ${ }^{5}$, movimento esse fundamental para o surgimento do comunismo operário. O Cartismo inglês,

\footnotetext{
${ }^{5} \mathrm{O}$ Cartismo caracterizou-se como um movimento social inglês que se iniciou na década de 30 , do século XIX, o qual foi fundado na luta pela inclusão política da classe operária. O cartismo teve sua origem na então criada, em 1792, London Corresponding Society. Segundo Coggiola (2016), a sociedade tinha como objetivos: "[...] o sufrágio universal, igualdade de representação, Parlamento honesto, fim dos abusos contra os cidadãos humildes, fim das pensões outorgadas pelo Parlamento aos membros das classes dirigentes, menor jornada de trabalho, diminuição dos impostos e entrega das terras comunais aos camponeses" (COGGIOLA, 2016, p. 14).
} 
assim denominado, por embasar-se na Carta do Povo, escrita em 1838, previa o voto universal e secreto com a abolição da qualificação, ou seja, o voto por nível de renda, bem como, abolia o pagamento aos membros do Parlamento.

Segundo Coggiola (2010), a estratégia utilizada pelos cartistas constituiu-se em torno da coleta de assinaturas, as quais eram realizadas nas oficinas, nas fábricas e em reuniões públicas, por meio de uma de uma série de petições nacionais, enviadas à Câmara dos Comuns. O Cartismo testemunhou o surgimento da classe operária no cenário social europeu, tal que não se limitava ao plano defensivo ou à atividade puramente sindical, mas também se projetava na ação política.

O Cartismo apresentou um programa democrático organizando as manifestações de massa a qual culminou com uma greve geral em 1842, inaugurando a prática dos "piquetes móveis" e, posteriormente, em 1847 conquistou a jornada de trabalho de dez horas, simbolizando a primeira vitória da classe operária a partir do movimento.

Em meados de 1848 o movimento Cartista já se demonstrava derrotado, mas deixou seu legado por ter constituído uma base das massas e, ainda, ter fundamentado, segundo, Coggiola (2016), duas reivindicações do operariado: “a) a redução da jornada de trabalho; e b) o sufrágio universal e secreto" (COGGIOLA, 2016, p. 15).

Nessas condições, o cartismo antecipou os debates do movimento operário divindindo os sujeitos em duas categorias: aqueles confiantes em uma aliança com os setores da burguesia por meio de uma pressão moral de suas reivindicações e os outros os quais acreditavam na ação direta dos operários pela organização das greves, que se tornou o núcleo do proletáriado fabril moderno.

A partir desse momento foi possível considerar o desenvolvimento social e político da classe operária para a superação do então socialismo constituído. Utopistas franceses como Saint-Simon e Fourier, bem como, Owen, inglês, representaram o início dos estudos sobre os fundamentos de uma sociedade baseada na luta de classes.

Há de se considerar, também, nesse mesmo período, a tendência radical das revoluções democráticas com propostas igualitárias que foram 
ganhando expressivamente o nome de comunismo. A revindicação da igualdade estava vinculada às condições sociais de vida dos sujeitos e não limitada a direitos políticos, na tentativa de terminar com diferenças existentes entre as classes.

Para Engels (1982), o comunismo constituia-se em um sistema de libertação do proletariado em que a terra deveria ser um bem comum dos homens tal que cada um deveria trabalhar de acordo com suas capacidades e, ao mesmo tempo, gozar e consumir de acordo com suas forças.

Nessa linha de pensamento, Engels afirmava sobre a necessidade de abolir a propriedade privada e, no seu lugar, estabelecer a utilização comum de todos os instrumentos de produção e a repartição de todos os produtos segundo acordo comum. A abolição da propriedade privada tornou-se a reivindicação principal por parte dos comunistas pela transformação da ordem social imposta pelo desenvolvimento da indústria. Sob esse enfoque, anunciou dez medidas as quais atacaram a propriedade privada e, de mesma forma, reconheceu que essas medidas possuiam poucas chances de serem empreedidas de uma única vez, ou seja, seria um processo de transformação gradual da passagem do capital, da produção e da troca para o Estado.

A partir disso o mesmo autor discutiu as diferenças entre o socialismo ${ }^{6} \mathrm{e}$ o comunismo tal que o primeiro ocupara-se com a reorganização da sociedade e das relações, mas não estabelecera um novo sistema, ou seja, propunha

\footnotetext{
${ }^{6}$ Engels (1982) divide os socialistas em três classes: I) Socialistas reacionários - consiste nos partidários da sociedade feudal e patriarcal que foi destruída. Apesar da dita compaixão pela causa do proletariado essa classe procura restabelecer o domínio da aristocracia, dos mestres das corporações e dos proprietários de manufaturas e no no momento em que o proletariado se torna revolucionário e comunista esses socialistas aliam-se a burguesia; II) Socialistas burgueses - consiste nos partidários da sociedade atual em que os males dela foram decorrentes e provocaram apreensões quanto à subsistência desta sociedade. Propõem medidas de beneficência e, ainda, grandiosos sistemas de reformas que sob o pretexto de reorganizarem a sociedade querem conservar as bases da sociedade atual; e III) Socialistas democráticos - são aqueles que pela mesma via que os comunistas, querem parte das medidas indicadas para transformação do modelo civilizatório, porém, não como meio de transição para o comunismo, mas como medidas que são suficientes para abolir a miséria e fazer desaparecer os males da sociedade atual. Estes socialistas democráticos ou são proletários que, ainda, não estão suficientemente esclarecidos sobre as condições da libertação da sua classe; ou são representantes dos pequenos burgueses, uma classe que, até à conquista da democracia e das medidas socialistas dela decorrentes, sob muitos aspectos tem os mesmos interesses que os proletários.
} 
diminuir as mazelas presentes no modelo capitalista, conservando a sociedade atual, ao contrário do comunismo que prevera o fim do modelo civilizatório capitalista.

Para Coggiola (2010), o pensamento socialista contemporâneo surgiu junto com o próprio modelo capitalista no momento em que expressou a sensibilidade de diversos setores sociais para com o caráter dramático e destrutivo das contradições e catástrofes sociais geradas pelo capitalismo.

Os pensadores socialistas ficaram convencidos de que a desagregação social teria fim com a abolição da propriedade privada dos meios de produção e, ao mesmo tempo, tomaram consciência de que as novas forças produtivas criadas pelo capitalismo (o sistema industrial) tornavam possível pela primeira vez na história à realização prática de uma utopia socialista, ou seja, a propriedade coletiva ou social dos meios de produção.

Com essas premissas Engels sugere a substituição dos Princípios básicos do comunismo pelo Manisfesto comunista por meio da inserção de elementos históricos que sua obra não continha. A ideia era, justamente, transformar o documento em uma exposição histórica, concentrando a nova concepção de mundo proposta. "A julgar pelo estilo, a forma definitiva do Manifesto deve-se principalmente a Marx, enquanto Engels, como demonstra o seu projeto, conhecia com a mesma clareza a ideias que foram expostas, merecendo plenamente o título de coautor" (COGGIOLA, 2016, p. 27).

\section{O MANIFESTO COMUNISTA: DIALÉTICA E REVOLUÇÃO}

Para Coggiola (2016), o ponto de partida histórico-universal e classista já estava contido nos Princípios básicos do comunismo e fora desenvolvido no Manifesto comunista, conforme princípios que permitiram a Marx e Engels a superação do hegelianismo no que concerne a questão-chave do Estado, pois Hegel, ainda, via o Estado sob uma forma abstrata.

Nesse sentido, para Marx e Engels o estado nasce dos antagonismos entre as classes, sendo que para a classe burguesa ele se constitui em pról dos interesses dessa. Essa concepção gerou uma ruptura qualitativa imposta 
pela era do capital na história universal. 0 capitalismo histórico ${ }^{7}$, com a mercantilização generalizada dos processos, veio a ser utilizado de um modo muito específico, tal que pela superação da produção mercantil, passou-se à concepção dialética da história, a qual incluiu as rupturas históricas.

Nessas condições, a concepção diáletica constitui-se oposta ao definido no método hegeliano. Em Hegel, o processo do pensamento transformador de um sujeito sob o nome de ideia é o criador do real, sendo esse a real manifestação externa. Na proposta marxista, o ideal não é mais do que o material transposto para o sujeito e por ele interpretado.

Assim, coloca-se o objeto como primeiro, assegurando a primazia dos conteúdos materiais e históricos, bem como as formas finitas da consciência, sobre as formas infinitas dessa mesma consciência, tal que se vincula o conhecimento a um objetivo concreto. Esse mesmo objeto que os seres humanos percebem ou criam é parte de um conhecimento totalizante ou de um processo de totalização. Ambos nunca são alcançadas como etapas definitivas ou acabadas. "A realidade é sempre mais rica do que o conhecimento que a gente tem dela. Há sempre algo que escapa às nossas sínteses; isso, porém, não nos dispensa do esforço de elaborar sínteses, se quisermos entender melhor a realidade" (KONDER, 1987, p. 37). A síntese se configura como uma visão de conjunto a qual permite desvelar a estrutura significativa da realidade ${ }^{8}$ em uma dada situação.

Outras duas categorias definidas no manifesto são os conceitos de classe e de bildung, formação, que mesmo reconhecendo seus antecedentes na obra Os princípios de Engels e em toda a obra constituída pelo próprio Marx é no Manifesto que Marx irá se referir ao proletariado como classe e, ainda, a

\footnotetext{
7 Para Immanuel Wallerstein no capitalismo histórico, o capital era usado com o objetivo de auto-expansão da economia mundo. Economia governada pela intenção racional de maximizar a acumulação. Afirma, ainda, que a trajetória do capitalismo histórico pautou-se na correlação entre a divisão e a valorização do trabalho.

${ }^{8}$ Para Konder (1987), a estrutura significativa da realidade constituída pela visão de conjunto chama-se totalidade. A totalidade está para além da soma das partes que a consituem. "A maior ou menor abrangência de uma totalidade depende do nível de generalização do pensamento e dos objetivos concretos dos homens em cada situação dada" (KONDER, 1987, p. 38).
} 
respectiva formação dessa classe. Para Coggiola (2016), em 1843, foi elaborada uma proposta ${ }^{9}$ na França, pela união geral dos operários e operárias, sem distinção de ofícios, com o fim de construir a classe operária, bem como, criar estabelecimentos para educar crianças e, ainda, acolher os operários doentes e feridos.

Ao mesmo tempo em que na França aconteceu essa efervescência o comunismo se tornava força política na Alemanha, ainda que juntamente com os ideais socilalistas já era uma proposta utilizada desde o ano de 1830. O comunismo ganhou proporção em 1842, momento em que Engels e Bakunin converteram-se a esse, produzindo a partir de então a propaganda comunista. A obra O Socialismo e comunismo na França contemporânea apresenta as "[...] investigações da difusão do socialismo francês entre operários alemães imigrantes no país" (COGGIOLA, 2016, p. 29). Engels em carta a Marx, reconheceu o progresso realizado pela propaganda, enfatizando, ainda, a respeito do recrutamento de novos partidários para o movimento. Informou, de mesma maneira, sobre os diferentes focos tomados pelo movimento.

Desse modo, Marx e Engels acrescentaram ao comunismo a capacidade de formular seus objetivos baseados em uma síntese de conhecimentos que nenhum dos téoricos, tanto franceses como ingleses, possuiam a época. Fezse reconhecido que nem o racionalismo francês tampouco o empirismo inglês conseguiram prover a filosofia da história a visão de que a totalidade do mundo forma um conjunto ordenado que possa ser compreendido e dominado intelectualmente.

Nessa mesma época, a ideia de intervenção, com conhecimento de causa, passou a tomar proporção, no processo de transformação histórica da sociedade. A partir do estudo científico da estrutura econômica da sociedade burguesa, a qual proporcionava a base teórica, era possível expor de forma

\footnotetext{
${ }^{9}$ A organizadora dessa proposta foi à operária francesa Flora Tristán. A obra União operária, escrita em 1843, propunha a elaboração de ideias como igualdade, direitos e autoemancipação as quais marcavam um sentimento de incômodo com as realidades do trabalho e da mulher que a cercavam. Em uma tentativa de demonstrar os problemas e as desvantagens desse modo de organização social, Flora Tristán descreveu os aspectos da vivência de operários como miseráveis e de mulheres como servas em um contexto que os desfavorecia completamente.
} 
popular um novo modo de intervenção, para além de um sistema utópico. Marx assumiu que o proletariado inglês e francês já estava consciente de sua tarefa histórica e que esse mesmo proletariado trabalhava para desenvolver essa consciência em outros.

Para o mesmo autor, um dos objetivos do Manifesto era constituir o partido comunista, partido esse internacional, composto por alemães dispersos pela Europa bem como por representantes exilados de grupos operários e comunistas de vários países. É reconhecido que o centro do Manifesto foi à elaboração de um programa para a revolução, a revolução proletária.

Marx conseguiu prever, dessa forma, a amplitude social dos acontecimentos, formulando um programa embasado nessa perspectiva o qual fez com que a burguesia, que não se ocupava do povo, em um segundo momento compreendesse o problema social em questão. Isso acarretou a criação de um espaço de contraposição direta entre a burguesia e o proletariado a partir de uma perspectiva sociopolítica.

É reconhecido que essa contraposição na Alemanha já se apresentava mais evoluída, em comparação a Inglaterra e a França, mas, ao mesmo tempo, nota-se que a revolução proletária alemã não logrou êxito nem tampouco obteve sucesso como democrática, burguesa. De um lado os proletários com, ainda, insuficientes pressupostos sociais e políticos e de outro a burguesia com o intuito de incluir no sistema as garantias necessárias, não como forma de dominação, mas para uma divisão do poder com as forças do passado.

Para Trotsky (2010) o proletariado tornou-se demasiado fraco, pois faltava-Ihe organização, experiência e conhecimento. O capitalismo desenvolveu-se para tornar necessária a abolição das antigas relações feudais, mas não o bastante para colocar a classe operária em primeiro plano, como força política decisiva.

Ainda para o mesmo autor, o conflito que se desenrolava no interior da revolução preparava o proletariado para a independência política, mas, de mesma forma, enfraquecia a energia e a unidade da ação, provocando um gasto de energias o que obrigava a revolução a não avançar, mesmo após os seus primeiros êxitos. Dessa forma, a revolução não se transformou em uma 
revolução socialista, mas permitiu a Alemanha um crescimento posterior da economia capitalista.

Para Coggiola (2016), o próprio Engels reconheceu que a revolução alemã veio atrelada a revolução francesa, tal que a burguesia demonstrou seu pavor em ser superada pela revolução social, não em função dos acontecimentos alemães, mas por motivo das jornadas de junho em Paris. Ainda para o mesmo autor, os eixos metodológicos do Manifesto mostraram-se corretos: a) A ideia de que a medição de desenvolvimento econômico e social devem ser mensurados em escala internacional, b) Em função das questões sociais e políticas em relação ao proletariado alemão, não foi possível repetir a revolução francesa ou a inglesa, e c) A revolução burguesa e a revolução proletária são dois movimentos de um mesmo processo revolucionário ininterrupto.

As revoluções levaram a uma desmobilização proletária, tal que na Inglaterra, França e Alemanhã aconteceu à perseguição e, posterior, dispersão dos trabalhadores pelo estrangeiro. Isso fez com que fossem multiplicadas as edições do Manifesto em outros países, tal que passou a existir um interesse pelas obras de Marx e Engels em outros idiomas.

\section{BURGUESES E PROLETÁRIOS}

O Manifesto comunista inicia sob a argumentação a respeito da luta de classes constituída na história, remetendo a categorias como homem livre e escravo, patrício e plebeu, senhor feudal e servo, dentre outras. Aqui se percebe a constante oposição entre opressores e oprimidos tal que, nessas condições, deu-se a destruição dessas classes por meio de uma transformação revolucionária.

Para Marx e Engels (2016), a sociedade burguesa moderna surgiu das ruínas da sociedade feudal e não aboliu os antagonismos de classe, pois estabeleceu, de mesma maneira, novas classes, burguesia e proletariado, com condições de opressão que não existiam no passado. "O proletariado não só era a classe explorada pela burguesia, criadora da riqueza que esta convertia em capital, como era a classe que crescia com o próprio capital" (GORENDER, 1998, p. 51). Ainda, para o autor, a observação da Revolução Industrial na 
Inglaterra, o único país capitalista plenamente constituído, permitia fazer a inferência acerca do potencial social de crescimento do proletariado, em comparação aos camponeses, aos artesãos e aos pequeno-burgueses.

O Manifesto comunista consistiu em propor ao movimento operário a substituição da esperança com a política pela fundamentação na ciência. Seu objetivo era levar à luta por objetivos políticos concretos a própria massa da classe operária.

Nessas condições, o objetivo final do documento deveria ser a conquista do poder do Estado e a implantação de um programa radical de transformação comunista da sociedade. O capitalismo deveria ser desfeito cedendo lugar a uma associação guiada pelo princípio moral do desenvolvimento livre de cada indivíduo como condição para o livre desenvolvimento de todos.

Com isso Marx atacou a burguesia argumentando que o Estado moderno tornara-se um comitê para gerir os negócios comuns de toda a classe burguesa, tal que a burguesia detinha a soberania política, bem como, exercia uma exploração aberta e direta. Essa exploração destruiu as relações feudais, patriarcais, substituindo as então relações dignas de homem para homem em simples valor de troca. O fato de a burguesia revolucionar os instrumentos de produção e com isso as relações de produção impactou diretamente nas relações sociais. "Dissolvem-se todas as relações sociais antigas e cristalizadas, com seu cortejo de concepções e de ideias secularmente veneradas; as relações que as substituissem tornaram-se antiquadas antes de se consolidarem" (MARX; ENGELS, 2016, p. 43).

Dessa forma, a burguesia, pela exploração do mercado mundial, deslocou a base da indústria nacional, momento em que tanto a matéria prima como os produtos produzidos passaram a ser comprados e consumidos em diferentes partes do mundo. Tal situação deixou o isolamento das nações para trás, criando uma interdependência entre as mesmas, levando em conta a produção material e intelectual.

Tal situação acarretou aos baixos preços dos produtos, obrigando as nações a adotarem essa forma de produção, necessitando cada vez mais de trabalhadores nas fábricas. Essa forma de desenvolvimento criou os grandes centros urbanos, fazendo com que as cidades aumentassem as suas 
populações em detrimento da população rural, fazendo com que os camponeses fossem subordinados aos burgueses.

Assim, a sociedade burguesa a partir de suas relações de produção e troca, fundamentada em um regime burguês de propriedade, pela livre concorrência, atingiu uma organização social e política a qual estabeleceu a supremacia econômica e política da própria classe burguesa. Para que se mantenha a estabilidade do sistema, vencendo as possíveis crises comerciais, há uma necessidade constante de por um lado exercer a destruição das forças produtivas e por outro conquistar novos mercados, pela exploração intensa dos antigos.

Com o desenvolvimento do capital, da burguesia, desenvolveu-se, de mesma maneira, a classe dos proletários, classe essa que só tem trabalho enquanto seu trabalho faz aumentar o capital. O emprego das máquinas e a divisão do trabalho ${ }^{10}$ retiraram do trabalhador seu caráter autônomo, reduzindo o custo desse sujeito. Essa redução de custo do trabalhador o fez aos níveis dos meios de subsitência desse.

Tal efeito remete ao raciocínio proposto por Marx de que quanto mais à indústria progredia mais explorado era o trabalhador, principalmente aqueles com menores habilidades e forças. Essa exploração constitui a classe dos assalariados formada por diferentes sujeitos, momento em que os trabalhadores estavam à mercê de outros membros da burguesia, como os varejistas, por exemplo.

Ao mesmo tempo, aqueles pequenos burgueses, como industriais ou comerciantes, sucumbiram à concorrência com os grandes capitalistas e passaram a compor, também, a mão de obra assalarida, o proletariado.

Com isso surgiram as primeiras lutas isoladas, posteriormente, operários de uma mesma fábrica e, ainda, de um mesmo ramo ou localidade contra a burguesia. Os ataques contra a burguesia formaram-se contra as relações

\footnotetext{
${ }^{10}$ Para Engels (1982), o trabalho foi dividido entre cada um dos operários, de maneira que o operário que, anteriormente, fizera uma peça inteira agora passou a fazer apenas uma parte dessa peça. Esta divisão do trabalho tornou possível que os produtos fossem fornecidos mais depressa e, ainda, mais baratos.
} 
burguesas de produção e contra os instrumentos de produção, por meio da destruição de máquinas e mercadorias, tal que os operários esforçavam-se para reconquistar a posição de trabalhador da Idade Média.

Para Marx, nessa fase o proletariado constituiu-se massa dispersa pela concorrência, momento em que a coesão dos operários tornou-se resultado da união burguesa e não resultado de sua própria união. Nessa fase, os proletários não combatiam seus próprios inimigos, "[...] mas os inimigos de seus inimigos, os restos da monarquia absoluta, os proprietários das terras, os burgueses não industriais, os pequenos-burgueses" (MARX; ENGELS, 2016, p. 47).

O aumento da concorrência entre os burgueses associada às crises comerciais, bem como, o aperfeiçoamento das máquinas, tornaram os salários instáveis o que levou aos operários a condições precárias. Isso fez com que esses sujeitos constituíssem alianças contra os burgueses atuando em comum para a defesa dos salários. A conquista dos salários, ainda era efêmera, mas a união entre os trabalhadores tornou-se significativa, como forma de luta de classes, luta política. Ao mesmo tempo, a organização do proletariado em partido político era destruída pela concorrência que faziam entre si os operários. Um exemplo conquistado à época foi a jornada de dez horas de trabalho na Inglaterra.

A questão a pontuar é que a burguesia vivia uma luta permanente com a aristocracia, bem como, com partes da própria burguesia cujos interesses estavam em conflito com o desenvolvimento da indústria. Em função dessas lutas a burguesia buscava recorrer ao proletariado e dessa forma envolvê-lo no movimento político, fornecendo a esses operários a educação política. De mesma maneira, os pequenos bugueses inseridos no proletariado proporcionavam, também, essa educação política.

Nesse contexto, as demais classes pereceram e o proletariado conseguiu manter-se como classe revolucionária em oposição à burguesia. As camadas médias, reacionárias, combateram também a burguesia, anteriormente, defendendo seu ponto de vista, mas, posteriormente, em favor do proletariado, dos interesses futuros. 
Assim, as condições de existência da velha sociedade fora destruída, tal que as relações de família do proletariado, sem propriedade, tornaram-se diferentes das condições das familias burguesas. Tal situação, fez com que os proletários não conseguissem se apoderar das forças produtivas sociais, a não ser que abolissem o modo de apropriação a eles correspondente.

\section{PROLETÁRIOS E COMUNISTAS}

A segunda parte do Manifesto questiona a relação dos comunistas com os proletários, momento em que Marx e Engels afirmaram que ambos não possuiam objetivos diferentes e tampouco que os comunistas proclamassem pressupostos particulares.

Para o autor, a distinção, estava em que os comunistas faziam prevalecer os interesses dos proletários, independentemente da nacionalidade, bem como, representavam os interesses do movimento em seu conjunto. Nessas condições, os comunistas representavam a parte dos proletários que estimularia aos demais, dada uma compreensão das condições e curso da revolução. O objetivo de ambos era constituir os proletários como classe com poder político, lutando, ainda, pela derrubada da burguesia com a abolição das relações de propriedade burguesa.

Essa propriedade burguesa representava a expressão do modo de produção e de apropriação baseado no antagonismo de classes, na exploração. A propriedade se movia entre capital e trabalho, tal que a propriedade explorava o trabalho assalariado e só poderia aumentar à medida que gerasse um novo trabalho assalariado. Isso fez com que o capital se tornasse um poder social. Já quando o capital fosse transformado em propriedade comum transformaria-se em propriedade social fazendo com que a propriedade perdesse seu caráter de classe.

O preço médio do salário era o mínimo o qual representava a soma dos meios de subsistência necessários para que o operário vivesse como tal. Dessa forma, "[...] o que o operário recebe com seu trabalho é o estritamente necessário para a mera conservação e reprodução de sua existência" (MARX; ENGELS, 2016, p. 53). Nessas condições, a proposta foi suprimir o caráter miserável dessa apropriação, evitando que o operário só vivesse para 
aumentar o capital, capital esse independente e pessoal, pois na sociedade burguesa o trabalho vivo era sempre meio de aumentar o trabalho acumulado. Já na sociedade comunista o trabalho acumulado visava sempre promover a existência dos operários.

Abolir a individualidade burguesa remeteu a supressão da liberdade dessa com a supressão da liberdade de comércio e da liberdade de comprar e vender. Assim, essa supressão passaria pelo momento em que o trabalho não poderia mais ser convertido em capital, em poder social, monopolizado.

Nesse contexto, surgiu também a necessidade de substituir a educação doméstica pela educação social, mesmo porque a intromissão da sociedade na educação era fator reconhecido, mas a proposta do Manifesto era de que se retirasse da educação a influência da classe dominante, preservando as crianças filhos dos proletários, para que deixassem de ser instrumentos de trabalho. Cabe ressaltar a necessidade de constituição de uma educação pública e gratuita para todas as crianças com a abolição do trabalho das crianças nas fábricas.

Para a burguesia, tanto as crianças filhas como as mulheres proletárias também representavam instrumentos de produção, exploradas em comum, tal que a abolição das relações de produção visava transformar a comunidade de mulheres, por exemplo, em uma comunidade franca e oficial.

Em relação à conquista do poder político por parte do proletário com a devida elevação a classe dirigente o fundamental é que esse proletário deveria tornar-se nação, nacional, ao contrário do sentido burguês da palavra. Essa ação comum seria a condição de emancipação da categoria, fazendo desaparecer a hostilidade entre as nações. "A medida que for suprimida a exploração do homem pelo homem, será suprimida a exploração de uma nação por outra" (MARX; ENGELS, 2016, p. 53).

Assim, percebe-se que a revolução comunista representou uma ruptura com as relações tradicionais de propriedade as quais romperam com as ideias tradicionais, ideias essas que estão fundamentadas em antagonismos de classes, antagonismos que se revestem conforme as diferentes épocas. Tal fundamentação impactou, ainda, nas ideias religiosas, morais, filosóficas e jurídicas. 
Os autores reconhecem que a retirada do capital da burguesia com a centralização dos instrumentos de produção ao controle do Estado, tendia a aplicação de medidas do ponto de vista econômico, que no desenrolar do movimento ultrapassariam a si mesmas e seriam fundamentais para a transformação radical.

Para os países adiantados Marx e Engels (2016) acentuaram a necessidade de expropriação da propriedade fundiária, impostos fortemente progressivos, abolição do direito de herança e confisco de propriedade de emigrados e rebeldes. Tratou-se, ainda, a centralização do crédito sob a responsabilidade do Estado, bem como, de todos os meios de comunicação e transporte. Também, a multiplicação das fábricas nacionais e dos instrumentos de produção, unificação do trabalho obrigatório e do trabalho agrícola e industrial e, por fim, a educação pública e gratuita.

Essas medidas proporcionariam ao proletariado por meio da revolução, não a destruição forçosa das relações de produção, destruindo as condições de existência dos antagonismos entre classes, mas a criação de uma associação na qual o livre desenvolvimento de cada um é condição para o livre desenvolvimento de todos.

\section{SOCIALISMO E COMUNISMO}

Diante do contexto do Manifesto surgiram categorias diferenciadas as quais forneceram apoio para a burguesia ou para o proletariado. No intuito de despertar a simpatia do proletariado, a aristocracia, socialismo feudal, dirigia acusações à burguesia, aparentando defender os interesses da classe operária. O socialismo feudal produzia uma dura crítica contra a burguesia, mas, ao mesmo tempo, era incapaz de acompanhar a marcha da história. A crítica estava associada à burguesia a qual sob seu regime colocara em risco o desenvolvimento da antiga ordem social. Nesse fato, a reprovação da burguesia está no fato dela ter produzido um proletariado revolucionário, não de tê-lo criado em geral.

Nessas condições, a aristocracia, em relação à luta política, participava de todas as medidas de represssão contra os operários, com seus interesses voltados ao comércio e a industria. 
Já os pequeno-burgueses ou pequeno-camponeses precursores da burguesia moderna formaram o socialismo pequeno-burguês, o qual oscilava entre o proletariado e a burguesia, como porção complementar da sociedade, os quais foram substituídos, aos poucos, no comércio, na manufatura e na agricultura por sujeitos como supervisores, capatazes e empregados.

O socialismo pequeno-burguês trouxe a tona as contradições nas relações de produção, demonstrando o efeito das máquinas, bem como, o efeito da divisão do trabalho. De mesma forma, trouxe, ainda, temas como a miséria do proletariado, a dissolução dos costumes, bem como, a desproporção na distribuição das riquezas.

Esse socialismo contribuiu para tentar restabelecer as antigas relações de propriedade e toda a antiga sociedade, bem como, por outro lado encarregou-se de fazer entrar a força os meios modernos de produção e de troca nas antigas relações de propriedade que acabaram por serem destruídas.

No socialismo alemão, ou ainda, no dito verdadeiro socialismo, a importação da literatura francesa foi perdendo sua significação prática imediata tomando um caráter lieterário. Não eram percebidas as condições de vida da França, tal que os pensadores alemães apropriaram-se das ideias francesas mantendo seu próprio ponto de vista filosófico. "Apropriaram-se delas da mesma forma com que se assimila uma língua estrangeira: pela tradução" (MARX; ENGELS, 2016, p. 62).

Como isso esses pensadores alemães, agindo em sentido inverso, introduziram ideias nos originais franceses e a essa interpolação puseram o nome de verdadeiro socialismo ou, ainda, filosofia da ação. No momento em que se acirraram as lutas entre a burguesia alemã e prussiansa contra o feudalismo e contra a monarquia absoluta o verdadeiro socialismo conseguiu se contrapuser ao movimento político e contra o liberalismo, pregando aos operários que nada tinham a ganhar com esse movimento.

Dessa maneira, o verdadeiro socialismo representou uma arma para os governos contra a burguesia, mas de outra forma, representou diretamente um interesse reacionário, interesse da pequena burguesia alemã. Esse socialismo tornou-se o representante da pequena burguesia, no momento em que colocou 
no centro o homem-modelo, o pequeno burguês alemão, levantando-se, por fim, contra a tendência do comunismo.

O socialismo conservador, ou burguês, era composto por economistas ou filântropos humanitários, organizadores de atividades de beneficência, com ideais reformadores das mazelas da classe proletária. Apregoavam que as condições de vida sociais deveriam acontecer sem lutas e sem os perigos que decorrem dessas. As propostas do socialismo conservador vão desde manter a sociedade atual minimizando, ou tentando deixar que exista, o ódio que o proletário sente em relação à burguesia ou, ainda, fazendo com que esses operários se afastem dos movimentos revolucionários, apregoando reformas administrativas realizadas sobre a base das relações burguesas, não afetando as relações entre capital e trabalho.

O socialismo conservador tornou-se uma figura de retórica, pois afirmava que a burguesia era a própria burguesia no interesse da classe operária.

O socialismo e o comunismo crítico-utópicos eram aqueles que exprimiam as reivindicalções do proletariado, pois representavam os sujeitos que compreenderam o antagonismo entre as classes, bem como, a ação dos elementos para dissolver a classe dominante, mas ao mesmo tempo, não perceberam, no início, um proletariado com iniciativa para a revolução.

Com o desenvolvimento dos antagonismos de classes propunham-se à procura de uma ciência social que permitisse criar leis sociais, tal que imaginavam a organização gradual e espontânea do proletariado, classe sofredora, em uma organização idealizada, pré-fabricada, por eles. Por outro lado, o desejo dos crítico-utópicos era melhorar as condições materiais de vida de todos os membros da sociedade, mesmo que isso afetasse os mais privilegiados, com apelos também a classe dominante.

Por fim, terminaram por rejeitar a ação política e a ação revolucionária atribuindo a força do exemplo como caminho. Esses pensadores fizeram com que as proposições sobre a nova sociedade ficassem apenas no horizonte da utopia. Mesmo reconhecendo que os pensadores crítico-utópicos, no início, foram revolucionários, a partir disso acabaram por se constituir, por seus seguidores, como movimento reacionário. 


\section{CONSIDERAÇÕES FINAIS}

É de se considerar que o processo histórico seguiu um rumo essencialmente diverso daquele antecipado por Marx e Engels. Justamente o proletariado mais forte, nos países capitalistas economicamente mais avançados, rejeitou a revolução socialista e deu preferência à conquista de benefícios reformistas no quadro da burguesia. As revoluções de inspiração socialista somente foram vitoriosas nos países de predominância camponesa, onde o proletariado era fraco. O fato de ser a classe explorada pelo capital não fundamentou necessariamente a propensão revolucionária do proletariado.

A proposta do Manifesto comunista foi à proclamação do desaparecimento da moderna propriedade burguesa, mas para isso dependia da aplicação de práticas e princípios e, conforme o próprio documento, dependente das condições históricas vigentes. Em 1872, Marx e Engels reconhecem a necessidade de atenção as medidas revolucionárias em função do desenvolvimento da indústria desde 1848, principalmente pelos progressos da classe operária e experiência adquirida, bem como, pelo desaparecimento da maior parte dos partidos políticos existentes.

Outro questionamento elaborado pelos autores em 1882, no prefácio a edição russa, tratou a possibilidade de transformar a antiga posse em comum da terra em propriedade comunista. Para os mesmos autores essa situação seria o ponto de partida para a revolução, de modo que a revolução russa complementasse a evolução comunista.

Já Engels, em 1890, no prefácio a edição alemã, reconhece que o Manifesto possui sua própria história e inicialmente foi saudado pelo socialismo científico, mas colocado em segundo plano pela reação que seguiu à derrota dos operários em Paris, em 1848. O autor enfatiza, de mesma maneira, que em 1864 os proletários reuniram-se na Associação Internacional dos Trabalhadores, instituição essa que existiu por apenas nove anos, o que desembocou em 1866, no Congresso em Genébra, e, posteriormente, em 1889, no Congresso Operário de París, com a fixação legal da jornada de oito horas de trabalho. 
Por fim, Engels, no prefácio a edição italiana em 1893, admitiu que a revolução de 1848 não foi uma revolução socialista, mas preparou os caminhos, pois as batalhas travadas não foram em vão, tal que há de se considerar a libertação da Itália e da Alemanha, até então enfraquecidas pela divisão e discórdia internas e sob o domínio estrangeiro. Em última análise, Engels afirmou que os frutos da revolução foram colhidos pela classe capitalista, pois a revolução de 1848 ajudou a restaurar a unidade e a autonomia das nações, fortalecendo a independência nacional.

Para Petras (2016), na contemporaneidade, o significado do Manifesto está na análise da estrutura e do impacto do modelo civilizatório capitalista sobre os traballhadores assalariados, tal que se torna importante 0 reconhecimento da categoria como classe, unida na luta por um processo transformador socialista como alternativa coerente frente ao capitalismo.

Para o mesmo autor, o Manifesto é "[...] muito preciso no delineamento da incoerência das 'alternativas democráticas'” (PETRAS, 2016, p. 253, grifo do autor), alternativas essas que apresentam conceitos políticos vagos que fortalecem ainda mais a concentração da propriedade e da riqueza.

Nessas condições, o Manifesto oferece um quadro básico para a compreensão das dinâmicas estruturais subjacentes ao capitalismo, fazendose reconhecido, também, como documento não acabado, mas que demonstra que a discussão sobe a consciência de classe está atrelada as consequências econômicas do capitalismo, para além de uma matriz social independente.

\section{REFERÊNCIAS}

COGGIOLA, O. Os inícios das organizações dos trabalhadores. Revista Aurora, ano IV, n. 6, 2010. p. 11-20.

COGGIOLA, O. 150 anos do manifesto comunista. In: MARX, K; ENGELS, F. Manifesto comunista. 1. ed. Revisada. São Paulo: Boi Tempo, 2016. p. 09-35. ENGELS, F. Princípios básicos do comunismo. In: MARX, K.; ENGELS, F. Obras escolhidas. v.1. Lisboa: Avante, 1982.

ENGELS, F. Prefácio [As lutas de classes na França de 1848 a 1850]. In: MARX, K. As lutas de classes na França. 1. ed. Revisada. São Paulo: Boi Tempo, 2012. 
ENGELS, F. Prefácio a edição inglesa de 1888. In: MARX, K; ENGELS, F. Manifesto comunista. 1. ed. Revisada. São Paulo: Boi Tempo, 2016. p. 74-78. GORENDER, J. A prova da história. O que está vivo e o que está morto no manifesto comunista? Revista Estudos Avançados. v.12, n.34, 1998, p. 5053.

KONDER, Leandro. O que é dialética. 17. ed. São Paulo: Brasiliense, 1987.

MARX, K; ENGELS, F. Manifesto comunista. 1. ed. Revisada. São Paulo: Boi Tempo, 2016.

PETRAS, J. O manifesto comunista: qual sua relevância hoje? In: MARX, K; ENGELS, F. Manifesto comunista. 1. ed. Revisada. São Paulo: Boi Tempo, 2016. p. 239-254.

TROTSKY, L. A teoria da revolução permanente: Balanços e perspectivas. São Paulo: Sundermann, 2010. 